\title{
Sex Differences in Ibogaine Antagonism of Morphine-induced Locomotor Activity and in Ibogaine Brain Levels and Metabolism
}

\author{
S. M. PEARL, $\dagger$ L. B. HOUGH,* D. L. BOYD* AND S. D. GLICK* \\ *Department of Pharmacology and Neuroscience, Albany Medical College, Albany, NY 12208 \\ $\dagger$ Department of Neuroscience, University of Pittsburgh, Pittsburgh, PA 15260
}

Received 18 April 1996; Accepted 30 July 1996

\begin{abstract}
PEARL, S. M., L. B. HOUGH, D. L. BOYD AND S. D. GLICK. Sex differences in ibogaine antagonismofmorphineinduced locomotor activity and in ihogaine brain levels and metaholism. PHA RMACOI. RIOCHEM BEHAV 57(4) 809-815, 1997.-The present study demonstrates that the putative antiaddictive agent ibogaine produces more robust behavioral effects in female than in male rats and that these behavioral differences correlate with higher levels of ibogaine in the brain and plasma of female rats. There were no differences in basal locomotor activity between the sexes, and the response of rats to ibogaine differed between the sexes even in the absence of morphine. Five $\mathrm{h}$ after receiving ibogaine $(40 \mathrm{mg} / \mathrm{kg}$, IP), antagonism of morphine-induced locomotor activity was evident in female but not in male rats. Either $19 \mathrm{~h}$ after administration of ibogaine $(10-60 \mathrm{mg} / \mathrm{kg}$. IP), or one h after administration of noribogaine $(5-40 \mathrm{mg} / \mathrm{kg}$, IP), a suspected metabolite, antagonism of morphine was significantly greater in female than in male rats. Brain and plasma levels of ibogaine (1 h) and noribogaine $(5 \mathrm{~h})$, measured by gas chromatography-mass spectrometry, were greater in females as compared with males receiving the same dose of ibogaine. Levels of both ibogaine and noribogaine were substantially lower at $19 \mathrm{~h}$ than at earlier times after ibogaine administration, contrary to a previous study in humans. For both sexes, subcutaneous administration of ibogaine $(40 \mathrm{mg} / \mathrm{kg}, \mathrm{IP}, 19 \mathrm{~h})$ produced greater antagonism of morphinc-induced locomotor activity than did a comparable intraperitoneal injection, consistent with previous studies from this laboratory demonstrating that the former route of administration produces higher levels of ibogaine in the brain. These data show that there are sex differences in the effects of ibogaine and that this may be due to decreased bioavailability of ibogaine in males as compared to females. (C) 1997 Elsevier Science Inc.
\end{abstract}

Ibogaine Noribogaine Morphine Locomotor activity Sex differences Route of administration

IBOGAINE, a naturally-occurring indole alkaloid, is currently being investigated as an antiaddictive agent. Anecdotal reports in humans suggest that a single dose of ibogaine can interrupt drug-seeking behavior in addicts for up to 6 months. In rats, ibogaine has been shown to produce prolonged decreases in morphine (5) and cocaine $(2,7)$ self-administration. Ibogaine has also been reported to antagonize morphineinduced dopamine release (14) and to antagonize morphineinduced locomotor activity in rats $(15,19)$.

The mechanism of action of ibogaine has yet to be determined. Based on studies of ibogaine affinity, ibogaine's mechanism may involve the kappa opioid receptor $(3,18,22,24)$ the NMDA subtype of glutamate receptor $(8,17,19,20,21,24)$, or the serotonin transporter $(16,24)$. A metabolite of ibogaine, noribogaine (16), has also been shown to have affinity for these receptors $(16,17,18)$. Noribogaine (12 hydroxyibogamine), like its parent compound, acutely decreases dopamine release in the nucleus accumbens, antagonizes morphine-induced locomotor activity, and decreases morphine and cocaine selfadministration (9). Elevated plasma levels of noribogaine were reported to persist for up to $24 \mathrm{~h}$ in humans after ibogaine administration in a representative male subject (16). Based on these results and the in vitro binding activity of noribogaine, it was speculated that noribogaine is responsible for the longlasting effects of ibogaine (16). Recently, this laboratory has developed sensitive and specific methods utilizing gas chromatography-mass spectrometry (GCMS) for measuring ibogaine (4) and noribogaine (Hough et al., in preparation). Using the latter method, we detected noribogaine in rats up to several $\mathrm{h}$ following ibogaine administration (Hough et al., in preparation).

To date no studies have been performed which examine

Requests for reprints should be addressed to Dr. Stanley Glick, Department of Pharmacology \& Neuroscience, Albany Medical College, A136, 47 New Scotland Ave., Albany, NY 12208, Phone: (518)262-5303, Fax: (518) 262-5799, Email: SGlick@ccgateway.amc.edu 
the effects of ibogaine in male versus female rats, despite an early report that the bioavailability of ibogaine may be higher in female than in male rats (12). Therefore, in the present study we wanted to determine if there are sex differences in the locomotor response of rats to ibogaine and in the ability of ibogaine to antagonize morphine-induced locomotor activity. Opioid-induced locomotor activity is thought to be correlated with changes in nucleus accumbens dopamine (13). Furthermore, using GCMS, we sought to determine if the levels of ibogaine and/or noribogaine in whole brain and plasma differ between the sexes in ibogaine-treated rats.

The influence of route of administration on ibogaine activity has yet to be detcrmincd, although it has bcen demonstrated previously (11) that ibogaine levels in whole brain and plasma of ibogaine-treated rats are significantly greater if ibogaine is administered subcutaneously rather than intraperitoneally. Thus, we also wanted to determine the effect of route of administration on ibogaine antagonism of morphine in both sexes.

\section{METHOD}

\section{Animals}

Female (250-275 g) and male (275-300 g) Sprague-Dawley rats (Taconic, Germantown, NY) were housed in groups of 3-4 and allowed food and water ad lib. The animals were maintained on a $12 \mathrm{~h}$ light cycle (lights on at 0700 ) in a room carefully controlled for heat and humidity.

\section{Drug Treatments}

For locomotor activity studies rats received ibogaine hydrochloride (10-60 mg/kg, IP, or $40 \mathrm{mg} / \mathrm{kg}, \mathrm{SC}, \mathrm{RBI}$, Natick, MA) or saline $(1 \mathrm{ml} / \mathrm{kg}$, IP or SC) 5 or $19 \mathrm{~h}$ before a saline $(1 \mathrm{mg} /$ $\mathrm{ml}, \mathrm{IP})$ or morphine challenge $(5 \mathrm{mg} / \mathrm{kg}$, IP, morphine sulfate, Mallinckrodt, St. Louis) or noribogaine hydrochloride (5-40 $\mathrm{mg} / \mathrm{kg}$, IP, NIDA) $1 \mathrm{~h}$ before a saline or morphine challenge. Each rat received only 1 dose of ibogaine, noribogaine or saline and were challenged with either saline or morphine. It should be noted that ibogaine produces whole body tremors in both sexes, but which appear to be more severe in females than in males, lasting 3-4 h after administration, thus making locomotor activity difficult to monitor until at least $5 \mathrm{~h}$ after administration. Since noribogaine does not produce noticeable tremors in either sex, activity studies could be performed $1 \mathrm{~h}$ after its administration. Immediately following the morphine or saline challenge injection locomotor activity was monitored for $3 \mathrm{~h}$. It should also be noted that ibogaine has previously been shown to not influence morphine metabolism (6), and morphine pretreatment has been shown to not influence ibogaine metabolism (19).

\section{Activity Measurements}

Locomotor studies were performed in cylindrical $(60 \mathrm{~cm})$ photocell activity cages with three intersecting light beams. Each time a light beam was broken a single activity count was recorded by a 386 computer with Med Associates software. Each experiment was begun immediately following the saline (1 $\mathrm{mg} / \mathrm{ml}, \mathrm{IP})$ or morphine challenge $(5 \mathrm{mg} / \mathrm{kg}, \mathrm{IP})$.

\section{Measurement of Ibogaine and Noribogaine}

Rats received ibogaine $(40 \mathrm{mg} / \mathrm{kg}, \mathrm{IP})$ and were sacrificed by decapitation 1, 5 or $19 \mathrm{~h}$ later. Trunk blood was collected into a $10 \mathrm{ml}$ Vacutainer tube (Becton Dickinson, Rutherford,
$\mathrm{NJ})$ containing heparin ( $1+3$ units) and centrifuged $(1000 \mathrm{~g}$, $5 \mathrm{~min}$ ). Brain tissue was homogenized in 5 volumes of either $0.4 \mathrm{~N} \mathrm{HClO}_{4}$ or $10 \%$ trichloroacetic acid (TCA) along with appropriate internal standards to measure ibogaine or noribogaine, respectively. Plasma $(0.5 \mathrm{ml})$ was mixed with an equal volume of acid. Samples were centrifuged $(20,000 \mathrm{~g}$ for 20 $\mathrm{min})$, and supernatant fractions were analyzed immediately, or frozen $\left(-80^{\circ} \mathrm{C}\right)$ for subsequent analysis.

\section{GCMS Assay of Ibogaine}

The assay has been recently described in detail (4). Briefly, aliquots $(1 \mathrm{ml})$ of perchloric acid supernatant fractions received $250 \mathrm{ng}$ of internal standard (O[Cd $]$-ibogaine) and were made strongly basic with $10 \mathrm{~N} \mathrm{KOH}$. Samples were then extracted in to hexane, back-extracted into $0.01 \mathrm{~N} \mathrm{HCl}$, and dried by vacuum evaporation. Residues were derivatized with trifluoroacetic anhydride (TFAA), reevaporated to dryness. resuspended in toluene, and analyzed by GCMS. Quantitative analysis was performed by multiple ion monitoring of $\mathrm{m} / \mathrm{e} 406$ (TFA ibogaine) and m/e 409 (TFA O-[ $\left.\mathrm{Cd}_{3}\right]$-ibogaine) at 9.9 min. A second ion for each derivative was also monitored to confirm identification in all cases (m/e 391 and 394 for TFA ibogaine and the internal standard, respectively). Standard curves were constructed by the addition of ibogaine and internal standard to tissue and plasma samples from ibogainefree animals.

\section{GCMS Assay of Noribogaine}

Details of the noribogaine method are described elsewhere (Hough et al., in preparation). The assay utilizes organic extraction, derivatization with heptafluorobutyrylimidazole (HFBI), and detection by GCMS. Supernatant TCA fractions containing unknowns or noribogaine standards $(1 \mathrm{ml})$ were aliquotted into $15 \mathrm{ml}$ polypropylene conical tubes (Sarstedt, Newton, NC) and received 1,000 ng of nortabernanthine (i.e., 13-hydroxyibogamine, kindly provided by Dr. S. Archer, Rensselaer Polytechnic Institute, Troy, NY) as an internal standard. Samples were titrated to $\mathrm{pH} 12$ with $950 \mathrm{ml}$ of $0.5 \mathrm{M}$ trisodium phosphate, mixed by vortex, and received a saturating amount of sodium chloride. Each tube was mixed by vortex, received $6 \mathrm{ml}$ of chloroform, and was extracted by $15 \mathrm{~min}$ of rapid mechanical shaking. Following centrifugation $(1,200 \times \mathrm{g}$ for $10 \mathrm{~min}$ ), the upper (aqueous) layer was aspirated to waste and the lower (organic) layer transferred by pipette to a tube containing $0.5 \mathrm{ml} 0.01 \mathrm{~N} \mathrm{HCl}$. The tubes were then shaken and centrifuged as before. The upper (aqueous) layer was transferred to a $1 \mathrm{ml}$ Reactivial (Pierce Chemical, Rockford, IL) and dried by vacuum evaporation. The residues were derivatized at $85^{\circ} \mathrm{C}$ with $\mathrm{HFBI}(20 \mathrm{ml}$, Pierce Chemical, Rockford, IL) for $1 \mathrm{~h}$, with brief vortex mixing every $10 \mathrm{~min}$. After cooling at room temperature for $30 \mathrm{~min}$, the samples then received toluene $(50 \mathrm{ml})$ and sodium phosphate buffer $(0.1 \mathrm{M}$, $\mathrm{pH} 8,100 \mathrm{ml}$ ). The vials were mixed, centrifuged $(5 \mathrm{~min})$, and the bottom (aqueous) layer was removed with a blunt syringe, followed by the addition of a second $100 \mathrm{ml}$ portion of buffer. After repeating the mixing and centrifugation steps, the aqueous layer was again removed and a few crystals of granular anhydrous sodium sulfate were added. After centrifugation, the toluene phase was analyzed by GC-MS with a combination Hewlett-Packard 5890 Gas Chromatograph/5970A Mass Selective Detector equipped with a 7673 Autosampler. Injections were performed automatically using a $2 \mu \mathrm{L}$ injection volume. The gas chromatograph was run in splitless mode with a DB$5 \mathrm{~ms}$ column ( $30 \mathrm{~m}$ length, $0.25 \mathrm{~mm}$ ID. $0.1 \mathrm{~mm}$ film thickness, 


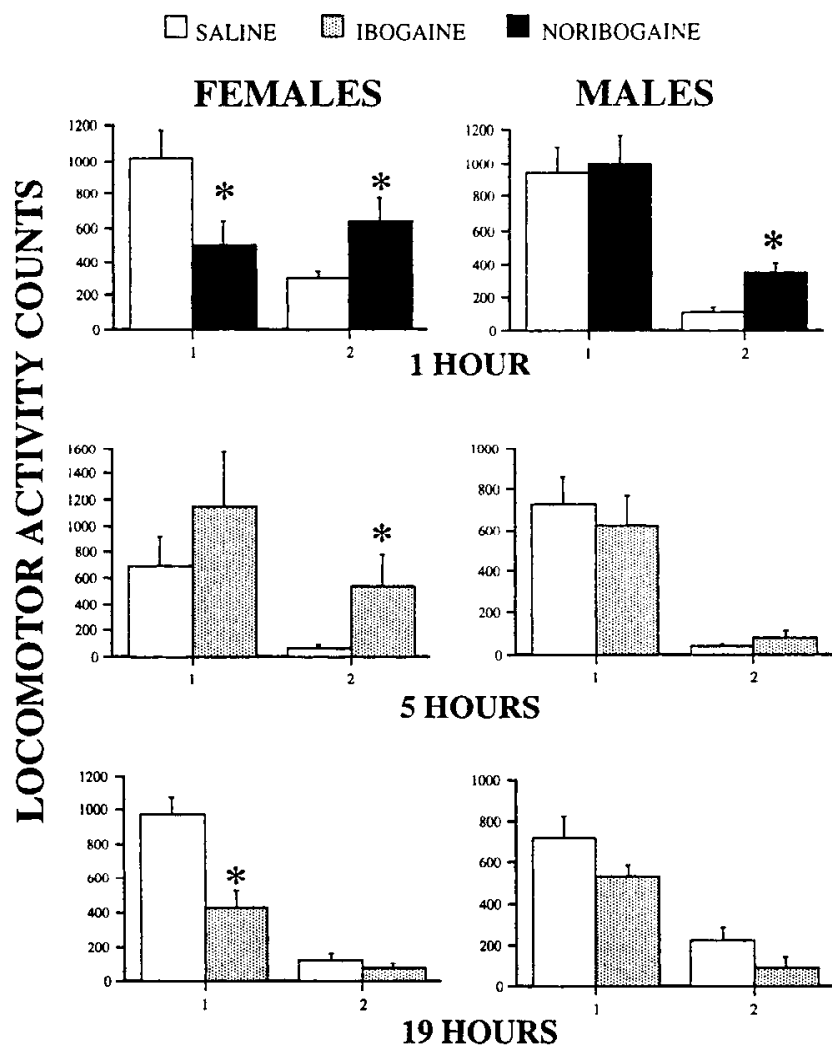

FIG. 1. The effects of ibogaine or noribogaine on basal locomotor activity (mean \pm SE for each of two h, " 1 " and " 2 ") in malc and female rats. Ibogaine $(40 \mathrm{mg} / \mathrm{kg}$, IP) or saline was administered 5 or $19 \mathrm{~h}$ before a saline $(1 \mathrm{mg} / \mathrm{ml}$, IP) injection (middle and bottom panels), whereas noribogaine or salinc was administcred $1 \mathrm{~h}$ before a saline challenge (top panels). There are at least 4 rats per group and *denotes significant difference from the saline-saline control group of the same sex.

from $J+W$ Scientific, Folsom, CA). The GC injector, oven, and detector temperatures were $210^{\circ}, 90^{\circ}$, and $335^{\circ} \mathrm{C}$, respectively. Separation of the noribogaine and nortabernanthine derivatives was accomplished by a temperature program starting at $90^{\circ} \mathrm{C}$ for $1 \mathrm{~min}\left(1 \mathrm{~min}\right.$ purge delay), increasing by $70^{\circ} \mathrm{C}$ min to a temperature of $230^{\circ} \mathrm{C}$, thereafter at $0.5^{\circ} \mathrm{C} / \mathrm{min}$ to a temperature of $240^{\circ} \mathrm{C}$, followed by $70^{\circ} \mathrm{C} / \mathrm{min}$ to a final temperature of $325^{\circ} \mathrm{C}$, which was held for $5 \mathrm{~min}$. Electron impact mass spectra were obtained $(-70 \mathrm{eV})$; computcrizcd data analysis was performed with HP ChemStation software. Noribogaine and nortabernanthine derivatives were detected and quantified by monitoring the molecular ion $\left(\mathrm{M}^{+}\right)$of both derivatives (HFB-noribogaine and HFB-nortabernanthine, respectively, both at $\mathrm{m} / \mathrm{e} 492$ ), which eluted at 11.2 and $11.5 \mathrm{~min}$, respectively. Monitoring of $\mathrm{m} / \mathrm{e} 407\left(35 \pm 20 \%\right.$ of $\left.\mathrm{M}^{+}\right)$was also performed to confirm all peak identities. In the presently described experiments, unknown samples were solved from standard curves which were linear from 50-1000 ng of noribogaine.

\section{Statistical Analysis}

Data were examined for main effects by analysis of variance (ANOVA) for treatment (dose), time and sex. If there were significant effects, the data wcrc decomposed and Least Sig-

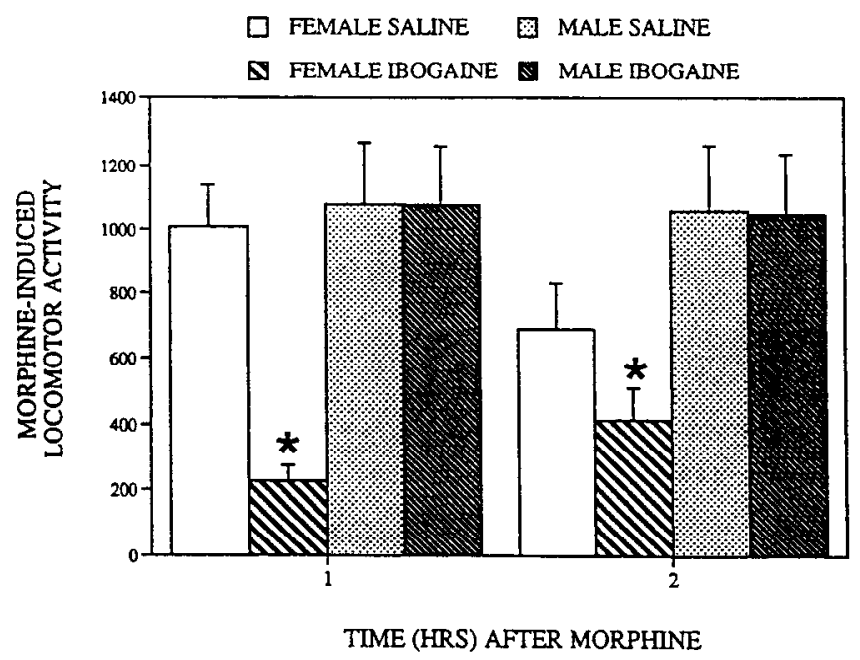

FIG. 2. The effects of ibogaine $(40 \mathrm{mg} / \mathrm{kg}$, IP) on morphine-induced $(5 \mathrm{mg} / \mathrm{kg}$, IP) locomotor activity (mean $\pm \mathrm{SE}$ ) in male and female rats. Ibogaine or saline was administered $5 \mathrm{~h}$ before the morphine challenge. There are at least 8 rats per group and *denotes significant difference from saline group of the same sex.

nificant Diffcrence (LSD) post hoc tests were performed (Statistica). GCMS data at 1 and 5 h were analyzed with ANOVA followed by LSD post hoc tests, GCMS data at $19 \mathrm{~h}$ were analyzed with a Kruskal-Wallis ANOVA by rank because some samples were not detectable at this time point.

\section{RESULTS}

Basal locomotor activity (i.e. following a saline injection) did not differ between the sexes at any time point (Fig. 1). One $\mathrm{h}$ after noribogaine treatment, in the absence of a morphine challenge, there was a significant effect of time $(F(1,14)=$ $17.46, p<0.000)$ and a time by noribogaine interaction $(F(1$, $14)=37.25, p<0.000)$ in females and a significant effect of time in males $(F(1,14)=54.5, p<0.000)$. Five $h$ after ibogaine treatment, with a saline challenge injection, there werc significant effects of time in females $(F(1,6)=19.48, p<0.004)$ and males $(F(1,6)=46.06, p<0.001)$. Nineteen $\mathrm{h}$ after ibogaine treatment there were significant effects of ibogaine treatment $(F(1,8)=17.71, p<0.002)$, time $(F(1,8)=76.87$, $p<0.00)$ and a significant time by ibogaine interaction $(F(1$, $8)=12.66, p<0.007$ ) in females. In males, $19 \mathrm{~h}$ after ibogaine and in the absence of a morphine challenge, there was a main effect of time $(F(1,8)=87.78, p<0.00)$.

Five $h$ after treatment, ibogaine $(40 \mathrm{mg} / \mathrm{kg}, \mathrm{IP})$ antagonized morphine-induced locomotor activity in female but not in male rats (Fig. 2). A 2-way ANOVA with repeated measures revealed significant effects of $\operatorname{sex}(F(1,28)=6.62,(p<0.02)$ and time $(F(2,56)=22.31,(p<0.000)$, and significant sex by time $(F(2,56)=11.73,(p<0.000)$, treatment by time $(F(2,56)=7.25,(p<0.02)$ and sex by treatment by time $(F(2,56)=8.92,(p<0.001)$ interactions. Subsequent ANOVA analysis of female data revealed significant effects of ibogaine treatment $(F(1,14)=4.23,(p<0.05)$ and a treatment by time interaction $(F(2,28)=29.75,(p<0.000)$.

Nineteen $h$ after ibogaine administration antagonism of morphine occurred to a greater extent and at lower doses in females as compared to males (Fig. 3). A 2-way ANOVA with 

$\square$ SALINE
区 $20 \mathrm{mg} / \mathrm{kg}$ IBO 目 $60 \mathrm{mg} / \mathrm{kg} \mathrm{IBO}$
图 $10 \mathrm{mg} / \mathrm{kg} \mathrm{IBO}$
$40 \mathrm{mg} / \mathrm{kg}$ IBO

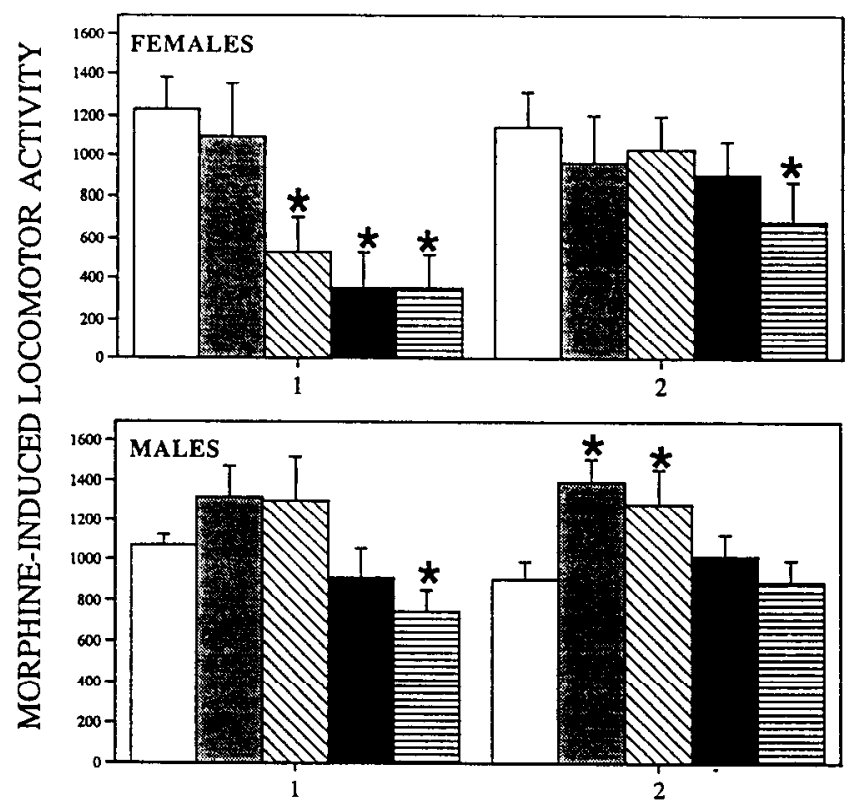

TIME (HRS) AFTER MORPHINE

FIG. 3. Dose-response effects of ibogaine $(10-60 \mathrm{mg} / \mathrm{kg}$, IP) or saline on morphine-induced $(5 \mathrm{mg} / \mathrm{kg}$, IP) locomotor activity (mean $\pm \mathrm{SE}$ ) in female (top panel) and male (bottom panel) rats. Ibogaine or saline was administered $19 \mathrm{~h}$ before the morphine challenge. There are at least 8 rats per group and *denotes groups which are significantly different from the saline group of the same sex.

repeated measures of all data demonstrated significant effects of sex $(F(1,111)=23.21,(p<0.000)$, ibogaine dose $(F(4$, $111)=6.72,(p<0.000)$ and time $(F(2,222)=86.78$ $(p<0.000)$ as well as significant interactions between sex and ibogaine dose $(F(4,111)=4.67,(p<0.002)$, dose and time $(F(8,222)=5.06,(p<0.000)$ and sex by dose by time $(F(8$, $222)=2.39,(p<0.02)$. ANOVA of female data indicated significant effects of ibogaine dose $(F(4,69)=5.27,(p<$ $0.001)$ and time $(F(2,138)=36.80,(p<0.000)$, and a significant dose by time interaction $(F(8,138)=6.02,(p<0.000)$. For male data, a ANOVA analysis revealed a main effect of ibogaine dose $(F(4,44)=6.58,(p<0.001)$. Interestingly, in males, a potentiation of morphine-induced locomotor activity was observed in the second $h$ following the morphinc challenge after ibogaine doses of 10 and $20 \mathrm{mg} / \mathrm{kg}$.

One $\mathrm{h}$ after noribogaine administration, a clear sex difference existed in the ability of noribogaine to antagonize morphine-induced locomotor activity (Fig. 4). For all the data there exist main treatment $(F(2,42)=7.70,(p<0.001)$ and time $(F(2,84)=8.66,(p<0.003)$ effects as well as the following interactions: sex by treatment $(F(2,42)=6.38$, $(p<0.004)$, sex by time $(F(2,84)=8.53,(p<0.001)$, treatment by time $(F(4,84)=12.76,(p<0.000)$ and sex by treatment by time $(F(4,84)-15.01,(p<0.000)$. For female data there were significant effects of treatment $(F(3,28)=$ 11.59, $(p<0.000)$ and time $(F(2,56)=4.73,(p<0.01)$ as well as a treatment by time interaction $(F(6,56)=11.61$, $(p<0.000)$. For males there was a significant effect of time $(F(2,42)=15.41,(p<0.000)$ and a treatment by time interac-

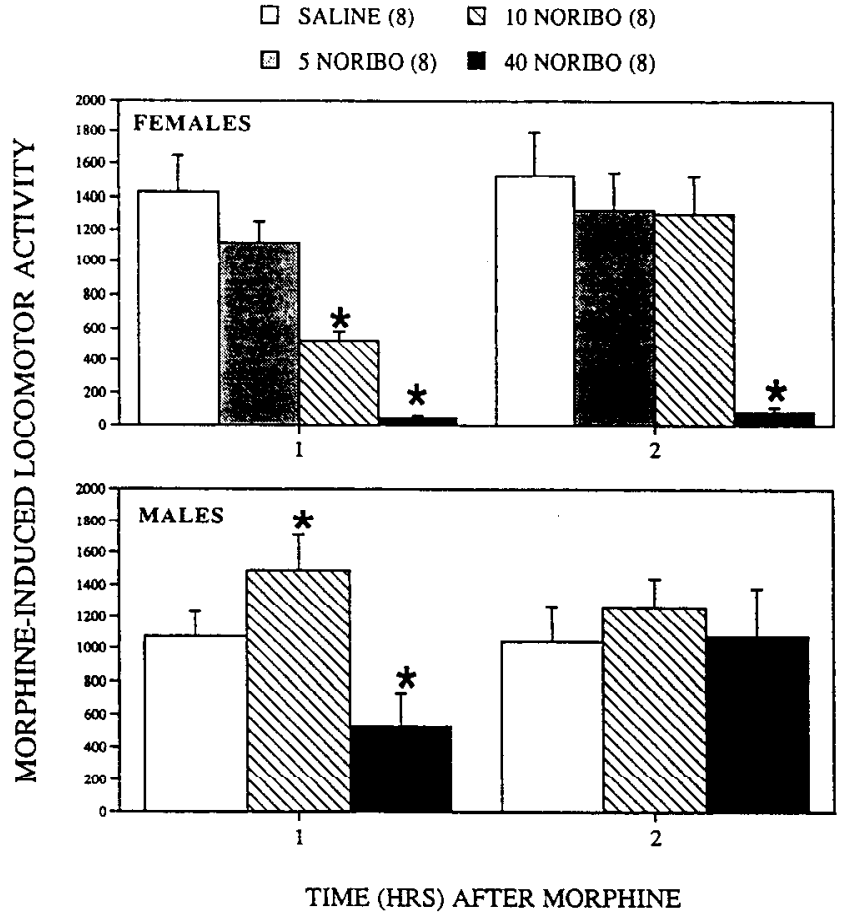

FIG. 4. The effects of noribogaine $(5-40 \mathrm{mg} / \mathrm{kg}$, IP) or saline on morphine-induced $(5 \mathrm{mg} / \mathrm{kg}$. IP) locomotor activity (mean $\pm \mathrm{SE}$ ) in female (top panel) and male (bottom panel) rats. Noribogaine or saline was administered one $\mathrm{h}$ before the morphine challenge. There are at least 8 rats per group and *denotes groups statistically different from the saline group of the same sex.

tion $(F(4,42)=12.91,(p<0.000)$. In males, similar to the data with ibogaine, there was a significant potentiation of morphine-induced locomotor activity following a low dose of noribogaine $(10 \mathrm{mg} / \mathrm{kg}, \mathrm{IP})$.

The levels of ibogaine in whole brain and in plasma of ibogaine-treated rats were greater in female than in male rats $1 \mathrm{~h}$ after ibogaine administration (LSD test $(p<0.05$, Figs. 5 and 6). The whole brain ibogaine levels illustrated in Figure 5 correspond approximately to 10,1 and $0.7 \mu \mathrm{M}$ in females and $6,0.9$ and $0.2 \mu \mathrm{M}$ in males at 1,5 and $19 \mathrm{~h}$, respectively. Plasma ibogaine levels (Fig. 6) correspond to approximately 0.5 and $0.3 \mu \mathrm{M}$ in females and males, respectively, at $1 \mathrm{~h}$ following ibogaine administration. Female brain and plasma levels of ibogaine at $1 \mathrm{~h}$ agree with previously published data (10). Plasma levels of ibogaine at 5 and $19 \mathrm{~h}$ were below the limit of detection (data not shown).

Brain and plasma levels of noribogaine were greater in female than in male rats $5 \mathrm{~h}$ after ibogaine administration (LSD test, $(p<0.04$, Figs. 5 and 6$)$. Brain levels of noribogaine in females correspond to approximately 20,10 and $0.8 \mu \mathrm{M}$ at 1,5 and $19 \mathrm{~h}$ respectively, and in males to approximately 13 , 7 , and $0.1 \mu \mathrm{M}$, respectively. Plasma levels of noribogaine (Fig. 6) indicate levels which are approximately $0.7,0.8$ and $0.03 \mu \mathrm{M}$ in females and $0.6,0.5$ and $0.01 \mu \mathrm{M}$ in males at 1,5 and $19 \mathrm{~h}$, respectively. Noribogaine brain levels at $19 \mathrm{~h}$ were detected in $3 / 5$ females and $4 / 5$ males, and ibogaine brain levels at this time were detected in $5 / 8$ females and $1 / 8$ males. Plasma noribogaine levels at $19 \mathrm{~h}$ were detected in $3 / 5$ females and $5 / 5$ males.

Route of administration plays a significant role in determin- 

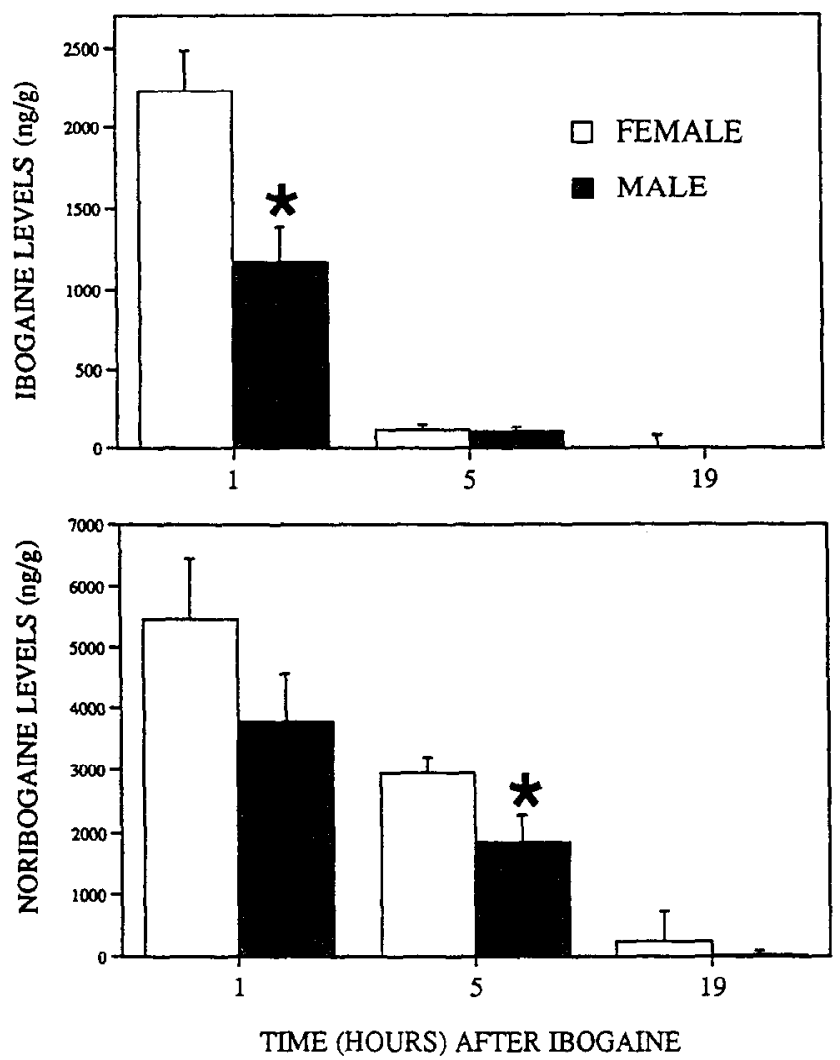

FIG. 5. Whole brain levels of ibogaine (top panel) and noribogaine (bottom panel) in female and male rats 1,5 and $19 \mathrm{~h}$ following ibogaine ( $40 \mathrm{mg} / \mathrm{kg}$, IP) administration. Levels of ibogaine and noribogaine at 1 and $5 \mathrm{~h}$ reflect mean \pm SEM values, whereas at $19 \mathrm{~h}$ they reflect median $+75 \%$. $\mathrm{N}=35$ per group. $*$ Denotes significant difference $(p<0.05)$ from the oppositc sex at the same timc point.

ing the efficacy of ibogaine antagonism of morphine-induced locomotor activity (Fig. 7), with SC administration of ibogaine producing greater antagonism of morphine-induced activity than a comparable IP dose. For all data there exist significant effects of route of administration $(F(1,69)=14.28,(p<$ $0.001)$ and ibogaine treatment $(F(1,69)=71.68,(p<0.000)$. Significant interactions occur between sex and route of administration $(F(1,69)=6.87,(p<0.01)$, sex and ibogaine treatment $(F(1,69)=22.05,(p<0.000)$, sex and time $(F(1,69)=7.79$, $(p<0.007)$, ibogaine treatment and time $(F(1,69)=5.69)$, $(p<0.02)$ and sex by ibogaine treatment by route of administration $(F(1,69)=11.58,(p<0.001)$. ANOVA of female data revealed significant effects of route of administration $(F(1,73)=7.50,(p<0.008)$ and ibogaine treatment $(F(1$, $73)=33.27,(p<0.000)$, and an interaction between ibogaine treatment and time $(F(1,73)=5.67,(p<0.02)$. ANOVA of male data revealed significant effects of ibogaine treatment $(F(1,42)=9.22,(p<0.004)$ and time $(F(1,42)=8.12$, $(p<0.007)$, as well as significant interactions between route of administration and time $(F(1,42)=4.86,(p<0.03)$ and route of administration and ibogaine treatment $(F(1,42)=$ $8.41,(p<0.006)$.

\section{DISCUSSION}

The present study shows that ibogaine influences locomotor activity differently in female and male rats, and that these

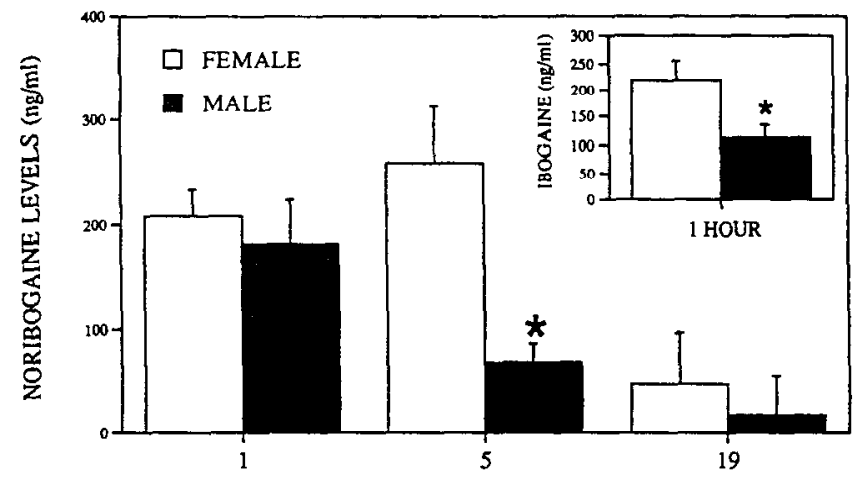

TIME (HOURS) AFTER IBOGAINE

FIG. 6. Plasma levels (mean $\pm \mathrm{SE}$ ) of noribogaine and ibogaine (inset) in female and male rats 1,5 and $19 \mathrm{~h}$ after ibogaine (40 mg/ $\mathrm{kg}$, IP) administration. Levels of ibogaine and noribogaine at 1 and $5 \mathrm{~h}$ reflect mean \pm SEM values, whereas at $19 \mathrm{~h}$ they reflect median $+75 \%$. There are 8 rats per ibogaine group and 5 rats pernoribogaine group. *Denotes significant difference from female group $(p<0.03)$ at comparable time point.

effects are not due to changes in basal levels of activity between the sexes. In addition, ibogaine antagonism of morphineinduced locomotor activity occurs to a greater extent in female than in male rats $(1,5$ and $19 \mathrm{~h})$ and whole brain and plasma levels of ibogaine $(1 \mathrm{~h})$ and noribogaine $(5 \mathrm{~h})$ are greater in female than in male rats. Since there are such high levels of noribogaine as compared to ibogaine in the brain (Fig. 5), this finding also suggests that noribogaine is, in fact, a major metabolite of ibogaine in rats and may contribute significantly to ibogaine's effects.

The differences in ibogaine levels seen $1 \mathrm{~h}$ after administration suggest that the amount of ibogaine reaching the plasma and brain compartments is greater in female than in male rats. This likely reflects a greater bioavailability of ibogaine in females as compared to males, as has been previously reported (12).

Our studies also show that there is a sex difference (females $>$ males) in noribogaine $5 \mathrm{~h}$ after ibogaine administration. This difference in noribogaine levels could account for the antagonism of morphine-induced locomotor activity seen in Fig. 1. These elevated noribogaine levels seen in females at $5 \mathrm{~h}$ is likely a reflection of the higher level of parent compound seen at earlier time points.

Nineteen $\mathrm{h}$ after ibogaine administration there were no differences in ibogaine or noribogaine levels between the sexes, despite robust differences in antagonism of morphine hyperactivity. These data seem to exclude both ibogaine and noribogaine as the agent that persists in the body and is responsible for the long-lasting effects of ibogaine. We cannot completely disregard the possibility that there are sex differences in ibogaine or noribogaine levels at $19 \mathrm{~h}$, however, because the levels are very low and near the limits of detection of the assays, making it difficult to establish possible sex differences at this time. It is also possible that another, as yet undiscovered, metabolite of ibogaine could be responsible for these longlasting effects. Furthermore, possibly the active agent does not need to persist in the body to cause a long-lasting effect; the active moiety may induce a post-receptor change at an early time point (before $19 \mathrm{~h}$ ) which influences the subsequent ability of morphine to activate dopaminergic systems.

It has been reported that, in humans, noribogaine persisted 
SALINE (IP+SC) $\square$ IBOGAINE IP $\mathbf{D}$ IBOGAINE SC

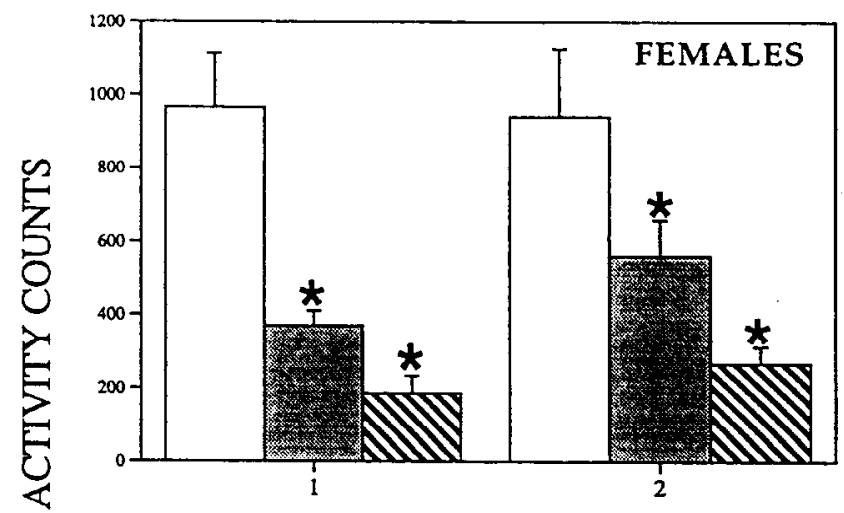

音

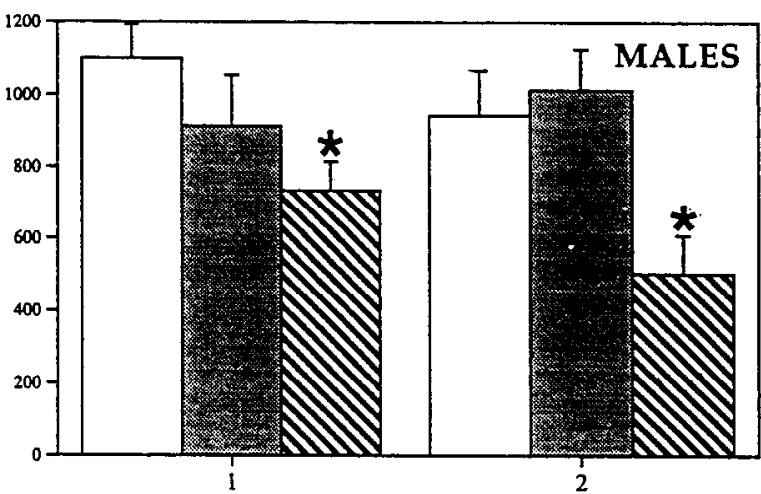

TIME (HRS) AFTER MORPHINE

FIG. 7. The effect of route of administration on ibogaine antagonism of morphine-induced locomotor activity (mean $\pm S E$ ). Rats were administered ibogaine $(40 \mathrm{mg} / \mathrm{kg}$ ) either intraperitoneally (IP) or subcutaneously (SC) $19 \mathrm{~h}$ before receiving a morphine challenge $(5 \mathrm{mg}$ / $\mathrm{kg}$, IP). The control group is a combination of rats which received saline either SC or IP; there was no difference between the groups. There are at least 8 rats per group and *denotes significant difference from the saline group of the same sex.

at high levels in the plasma of ibogaine-treated humans for at least $24 \mathrm{~h}(16)$. In the present study, neither ibogaine nor noribogaine persisted at high levels in either plasma or brain of rats $19 \mathrm{~h}$ following the administration of ibogaine. The amount of ibogaine and noribogaine remaining $19 \mathrm{~h}$ after ibogaine administration, however, may still produce pharmacological actions at the kappa and NMDA receptors, or at the scrotonin transporter, putative sites of ibogaine action. The reason that we find substantially diminished noribogaine levels at $19 \mathrm{~h}$ but others (16) report persisting high levels of noribogaine at $24 \mathrm{~h}$ may be due to differences in species, GCMS methods or doses and routes of administration. As we have demonstrated here (Fig. 6) and as has been previously shown (11), route of administration plays an important role in determining both the ability of ibogaine to antagonize morphine and the level of ibogaine in tissues and in plasma. Our data showing that subcutaneous administration of ibogaine produces a greater antagonism of morphine is likely the result of higher levels of ibogaine in the brain and plasma following subcutaneous administration as compared to the intraperitoneal route (11).

Why ibogaine levels differ between the sexes is not known at this time. However, the differences could be due to sex hormones and their interactions with enzymes involved with ibogaine metabolism. The O-demethylation of ibogaine to noribogaine in the body presumably involves a P450 cytochrome. P450 cytochromes have been demonstrated to produce sex-dependent effects. For example, it has been previously reported that mouse renal $\mathrm{P} 450$ levels are regulated by androgens (10) and that expression of rat hepatic P450 cytochromes are regulated by sex hormones $(1,23)$. It thus seems possible that the $\mathrm{P} 450$ enzyme involved in ibogaine's metabolism could be one which is influenced by sex hormones and may contribute to the difference in drug levels reported presently.

In this study, it was interesting to note that low doses of both ibogaine and noribogaine produced a potentiation of morphine-induced locomotor activity in males (Figs. 2 and 3). It appears that this potentiation does not occur in females, even at very low doses, as we have subsequently tested a very low dose of ibogaine $(2.5 \mathrm{mg} / \mathrm{kg}, \mathrm{IP})$ and found that it had no effect on morphine-induced locomotor activity (data not shown). This suggests that in male rats ibogaine produces biphasic effects on morphine, with potentiation of morphine actions occurring at low doses and antagonism occurring at higher doses of ibogaine. Of course, it is possible that ibogaine also produces biphasic effects on morphine responses in female rats, but that the stimulatory effect may be masked by a more predominant antagonistic effect in females.

The present data are consistent with a previous study (12) which reported that "peak plasma levels" of ibogaine, following oral $\left[{ }^{3} \mathrm{H}\right]$ ibogaine administration, were approximately three-fold higher in females than in males, and that the bioavailability of ibogaine was approximately two-fold higher in female than in male CD rats.

The present study shows that there are substantial sex differences in both ibogaine levels in the brain and plasma and in the ability of ibogaine to antagonize morphine. The importance of this finding in terms of the clinical use of ibogaine as an antiaddictive agent warrants further study.

\section{ACKNOWLEDGEMENTS}

This work was supported by DA05640 (S.M.P.) and DA03817 (S.D.G.).

\section{REFERENCES}

1. Bandiera, S.: Ryan, D. E.: Levin, W; Thomas, P. E.: Age- and sex-related expression of cytochrome $\mathrm{P} 450 \mathrm{f}$ and $\mathrm{P} 450 \mathrm{~g}$ in rat liver. Arch. Biochem. Biophys. 248:658-676; 1986

2. Cappendijk. S. L. T.; Dzoljic, M. R.: Inhibitory effects of ibogaine on cocaine self-administration in rats. Eur. J. Pharmacol. 241:261$265 ; 1993$
3. Deecher, D. C.; Teitler, M.; Soderlund, D. M.; Bornmann, W. G.; Keuhne, M. E.; Glick, S. D.: Mechanism of action of ibogaine and harmaline congeners based on radioligand binding studies. Brain Res. 571:242-247; 1992

4. Gallagher, C. A.; Hough, L. B.; Keefner, S. M.; Seyed Mozaffari, A.: Archer, S.; Glick, S. D.: Identification and quantification of 
the indole alkaloid ibogaine in biological samples by gas chromatography-mass spectrometry. Biochem. Pharmacol. 49:73-79; 1995.

5. Glick, S. D.; Rossman, K.; Steindorf, S.; Maisonneuve, I. M.; Carlson, J. N.: Effects and aftereffects of ibogaine on morphine self-administration in rats. Eur. J. Pharmacol. 195:341-345; 1991.

6. Glick, S. D.; Gallagher, C. A.; Hough, L. B.: Rossman, K. L.; Maisonneuve, I. M.: Differential effects of ibogaine pretreatment on brain levels of morphine and $(+)$-amphetamine. Brain Res. 558:173-176; 1992.

7. Glick, S. D.; Keuhne, M. E.; Raucci, J.; Wilson, T. E.; Larson, D.; Keller, R. W. Jr; Carlson, J. N.: Effects of iboga alkaloids on morphine and cocaine self-administration in rats: relationship to tremorigenic effects and to effects on dopamine release in nucleus accumbens and striatum. Brain Res. 657:14-22; 1994.

8. Glick, S. D.; Maisonneuve, 1. M.; Pearl, S. M.: Mechanism of action of ibogaine: interaction between kappa agonist and NMDA antagonist effects. College on Problems of Drug Dependence Annual Meeting: 1996.

9. Glick, S. D.; Pearl, S. M.; Cai, Z.; Maisonneuve, I. M.: Ibogainelike effects of noribogaine in rats. Brain Res 713:294-297; 1996.

10. Henderson, C. J.; Scott, A. R.; Yang, C. S.; Wolf. C. R.: Testosterone-mediated regulation of mouse renal cytochrome $\mathrm{P}-450$ isoenzymes. Biochem. J. 266:675-681; 1990.

11. Hough, L. B.; Pearl, S. M.; Glick, S. D.: Tissue distribution of ibogaine after intraperitoneal and subcutaneous administration. Life Sci. 58:119-122: 1995.

12. Jeffcoat, A. R.; Cook, C. E.; Hill, J. M.; Coleman. D. P.: Disposi-

- tion of $\left[{ }^{3} \mathrm{H}\right]$ Ibogaine in the rat. College on Problems of Drug Dependence Annual Meeting; 1993.

13. Joyee, E. M.; Iversen, S. D.: The effect of morphine applied locally to mesencephalic dopamine cell bodies on spontaneous motor activity in mice. Neurosci. Lett. 14:207-212; 1979.

14. Maisonneuve, I. M.; Keller, R. W. Jr.; Glick, S. D.: Interactions between ibogaine, a potential antiaddictive agent, and morphine: an in vivo microdialysis study. Eur. J. Pharmacol. 199:35-42: 1991.

15. Maisonneuve, I. M.; Rossman, K. L.; Keller, R. W. Jr; Glick, S. D.: Acute and prolonged effects of ibogaine on brain dopamine me- tabolism and morphine-induced locomotor activity in rats. Brain Res. 575:69-73: 1992 .

16. Mash, D. C.: Staley, J. K.: Baumann, M. H.; Rothman, R. B.: Hearn, W. L.: Identification of a primary metabolite of ibogaine that targets serotonin transporters and elevates serotonin. Life Sci. 57:45-50: 1995 .

17. Mash, D. C.; Staley, J. K.; Pablo, J. P.; Holohean, A. M.; Hackman, J. C.: Davidoff, R. A.: Properties of ibogaine and its prinicipal metabolite (12-hydroxyibogamine) at the MK-801 binding site of the NMDA receptor complex. Neurosci. Lett. 192:53-56; 1995.

18. Pearl, S. M.; Herrick-Davis, K.; Teitler, M.; Glick, S. D.: Radioligand binding study of noribogaine, a likely metabolite of ibogaine. Brain Res. 675:342-344; 1995.

19. Pearl, S. M.; Johnson, D. W. Glick, S. D.: Prior morphine enhances ibogaine antagonism of morphine-induced locomotor stimulation. Psychopharmacology 121:470-475; 1995.

20. Popik, P.; Layer, R. T.; Skolnick, P.: The putative anti-addictive drug ibogaine is a competitive inhibitor of $\left[{ }^{3} \mathrm{H}\right] \mathrm{MK}-801$ binding to the NMDA receptor complex. Psychopharamcology 114:672674; 1994.

21. Popik, P.; Layer, R. T.; Fossom, L. H.; Beneviste, M.; GeterDouglass, B.; Witkin, J. W.: Skolnick, P.: NMDA antagonist properties of the putative antiaddictive drug, ibogaine. J. Pharmacol. Exp. Ther. 275:753-760; 1995.

22. Repke, D. B.; Artis, D. R.; Nelson, J. T.; Wong, E. H. F.: Abbreviated ibogaine congeners. Synthesis and reactions of tropan3yl-2- and 3-indoles. Investigation of an unusual isomerization of 2-substituted indoles using computational and spectrscopic techniques. J. Org. Chem. 59:2164-2171; 1994.

23. Shapiro, B. H.; Pampori, N. A.; Lapenson, D. P.; Waxman, D. J.: Growth hormone-dependent and -independent sexually dimorphic regulation of phenobarbital-induced hepatic cytochromes P450 2B1 and 2B2. Arch. Biochem. Biophys. 312:234-239; 1994.

24. Sweetnam, P. M.; Lancaster, J.; Snowman, A.; Collins, J. L.; Perschke, S.; Bauer, C.; Ferkany, J.: Receptor binding profile suggests multiple mechanisms of action are responsible for ibogaine's putative anti-addictive activity. Psychopharamacology 118:369-376; 1995. 